\title{
Epulis gravidarum with histological features of plasma cell granuloma associated to herbal toothpaste: A case report
}

\author{
Dewi Zakiawati ${ }^{1}$ and Irna Sufiawati ${ }^{1}$ \\ ${ }^{1}$ Universitas Padjadjaran
}

November 9, 2021

\begin{abstract}
Hormonal imbalance during the pregnancy may predispose a localized gingival enlargement called epulis gravidarum. This paper aims to elaborate on a case of epulis gravidarum with histological features of plasma cell granuloma. Theoretically, they present in different histological features. However, in this case, the histological examinations showed both entities.
\end{abstract}

\section{Hosted file}

Clinical Case Reports- Epulis Main manuscript.docx available at https://authorea.com/users/ 445256/articles/544832-epulis-gravidarum-with-histological-features-of-plasma-cellgranuloma-associated-to-herbal-toothpaste-a-case-report 